\title{
A Framework for Developing an Effective Mission Statement
}

\author{
Daniel S. Cochran \\ Mississippi State University • Mississippi State, MS \\ Fred R. David \\ Francis Marion University - Florence, SC \\ C. Kendrick Gibson - Deceased \\ Henderson State University - Arkadelphia, AR
}

\section{Introduction}

An increasing number of profit and nonprofit organizations across America are incorporating strategic management activities into their overall operations. Strategic management can be defined as the formulation, implementation, and evaluation of actions that will enable a firm to achieve its objectives. The strategic management process is based on the belief that a firm should continually monitor key internal and external events and trends; firms should seek to pursue strategies that capitalize on internal strengths, take advantage of external opportunities, improve internal weaknesses, and minimize the effect of external threats. It is widely acknowledged today that the rate, magnitude, and complexity of changes that impact organizations are accelerating. These changes are creating a different type of consumer, different types of products and services, and consequently a need for different strategies. Increased competitiveness worldwide, coupled with rapid social, technological, and economic changes, are major reasons why the strategic management process is being adopted by more and more firms.

In a recent review of strategic management models, the mission statement was noted as being an essential first step in the strategic management process (David, 1984; Staples \& Black, 1984). A mission statement can be defined as an enduring document of purpose that distinguishes one business from other firms of its type (Pearce, 1982). A mission statement is a declaration of an organization's business or "reason for being." A clear statement of a company's mission is essential to effectively establishing objectives, formulating strategies, setting goals, devising policies, allocating resources, and motivating employees. A mission statement is thus an integral component of the strategic management process. As evidenced in the following quotation from Peter Drucker's classic book entitled Management: Tasks, Responsibilities, and Practices, a good mission statement makes strategy formulation, strategy implementation, and strategy evaluation much easier.

Unless the basic concepts on which a business has been built are visible, clearly understood, and explicitly expressed, an organiza- 
tion is at the mercy of events. Not understanding what it is, what it represents, and what its basic concepts, values, policies, and beliefs are, a business cannot rationally change itself. Only a clear definition of the mission and purpose of the business makes possible clear and realistic business objectives. The business mission is the foundation for priorities, strategies, plans, and work assignments. It is the starting point for the design of managerial jobs and, above all, for the design of managerial structures. Structure follows strategy. Strategy determines what the key activities are in a given business. And strategy requires knowing "what our business is and what it should be." (Drucker, p. 75).

The importance of a mission statement to effective strategic management is well supported in the management literature (Staples \& Black, 1984). A mission statement may be the most visible and public part of a strategic plan. As such, steps should be taken to insure that the statement includes all of the essential components and attributes. In addition, a company mission should be evaluated to insure that it communicates clearly the desired feelings that will guide and motivate employees to action.

The purpose of this article is to present a practical framework for developing an effective mission statement. A developmental model is presented and exemplified through application to actual organizations. The proposed mission statement developmental framework is presented in Figure 1, and includes the following four stages: Orientation, Component Analysis, Communication Analysis, and Applicability Analysis.

\section{Figure 1}

Steps in the Development of an Effective Mission Statement (MS)

Orientation

- Create a Strategic Planning Task Force

- Review the Strategic Planning Process

- Review Mission Statement Significance in Strategic Planning

- Review MS development process

Component Analysis

- Identify desired components

- Draft MS including derived components

Communication Analysis

Denotative Analysis

(Readability)

- Write clear and concise

- Compute Fog Index

- Rewrite if necessary 
Connotative Analysis

- Identify connotative feelings desired from reading MS

- Administer Questionnaire to users (readers)

- Rewrite if necessary

Applicability Analysis

- Identify likely situations where MS might be applied - develop case

- Have users evaluate case based on Mission Statement

- Determine if Mission Statement can be applied

A strategic planning task force is an appropriate group to do the initial development of an organization's mission statement. However, if this group is too large, a sub-committee could be developed called a "mission statement committee" and charged with going through the suggested stages presented in this paper.

\section{Orientation Process}

The purpose of orientation is to insure that individuals in the strategic planning task force understand the strategic management process. This orientation training should raise the level of awareness about particular individual's significance and role in planning. A training session would include the following: an overview of the strategic management process, a review of the significance of the mission statement to strategic management, and an introduction into the development process used to design an effective mission statement for their organization.

The process of developing a mission statement involves rendering differences of opinion. This is a vital part of achieving an appropriate mission statement for a firm. The task force must become aware that the process the organization goes through in coming to consensus in the development of the mission statement is as important as the output of the process - the mission statement itself.

\section{Component Analysis}

Given the understanding of what a mission statement is, the components of such a statement are important. The strategic planning task force must identify the major components to be included in their mission statement. Pearce (1982) recently identified eight key components of mission statements: customers, products or services, markets, technology, concern for survival, growth, and profitability, philosophy, self-concept, and concern for public image. These components could be used as a guideline by the committee. According to Pearce, a well conceived mission statement answers the following questions about an organization: 
1. Customers - Who are the enterprise's present and future customers?

2. Products or services - What are the firm's major products or services?

3. Markets - Where does the firm compete?

4. Technology - What is the firm's basic technology?

5. Concern for survival, growth, and profitability - What is the firm's attitude towards economic goals?

6. Philosophy - What are the basic beliefs, values, aspirations, and philosophical priorities of the firm?

7. Self-concepts - What are the firms' major strengths and competitive advantages?

8. Concern for public image - What is the firm's public image?

An actual example for each component is included in Table 1. The mission statement Committee would write a draft Mission Statement from their derived components. Actual company examples of each component is included in Table 1. The Mission Statement committee would use these components as a guide in developing their initial Mission Statement draft. Various idea generation techniques* such as Nominal Grouping or Brainstorming could be used to identify other important components for inclusion in this initial draft.

\section{Table 1}

\section{Identifying Mission Statement Components:}

\section{A Compilation Of Excerpts From Actual Mission Statements}

\section{Excerpts From Corporate Mission Statements}

1. Customers

2. Product or Service

3. Markets

4. Technology
We believe our first responsibility is to the doctors, nurses, and patients, to mothers and all others who use our products and services. (Johnson \& Johnson)

To anticipate and meet market needs of farmers, ranchers, and rural communities within North America. (CENEX)

AMAX's principal products are molybdenum, coal, iron ore, copper, lead, zinc, petroleum and natural gas, potash, phosphates, nickel, tungsten, silver, gold, and magnesium. (AMAX)

We are dedicated to the total success of Corning Glass Works as a worldwide competitor. (Corning Glass)

Control Data is in the business of applying micro-electronics and computer technology in two general areas: computerrelated hardware; and computing-enhancing services, which 
5. Concern for Survival

6. Philosophy

7. Self-Concept

8. Concern for Public Image include computation, information, education and finance. (Control Data)

The common technology in these areas relates to discrete particle coatings. (NASHUA)

In this respect, the company will conduct its operations prudently, and will provide the profits and growth which will assure Hoover's ultimate success. (Hoover Universal)

We are committed to improve health care throughout the world. (Baxter Travenol)

We believe human development to be the worthiest of the goals of civilization and independence to be the superior condition for nurturing growth in the capabilities of people. (Sun Company)

Hoover Universal is a diversified, multi-industry corporation with strong manufacturing capabilities, entrepreneurial policies, and individual business unit autonomy. (Hoover Universal)

We are responsible to the communities in which we live and work and to the world community as well. (Johnson \& Johnson) Also, we must be responsive to the broader concerns of the public including especially the general desire for improvement in the quality of life, equal opportunity for all, and the constructive use of natural resources. (Sun Company)

\section{Excerpts From University Mission Statements}

1. Customers

Thus, Winthrop fully accepts its role as a forum for public examination of issues as part of its responsibilities, not only to its students, but to all the citizens of South Carolina. (Winthrop College)

2. Product or Service

\section{Markets}

4. Technology

The School of Business Administration has the role of providing at both the undergraduate and graduate levels a sound education and high quality professional training in the broad field of administration for prospective managers and staff specialists ... rendering professional public service in the form of educational programs, research, consultation and assistance to Montana organizations .... (University of Montana)

To develop a partnership with business, community and government leaders and alumni in the Detroit Metropolitan area, serving one of the most influential industrial metropolitan areas in the world. (University of Detroit)

... to expand the involvement of faculty in research endeavors in the various fields of business and economics by providing ... ample computer facilities .... (Arkansas State University)

5. Concern for Use human and financial resources in creative ways to purSurvival
Use human and financial resources in creative ways to pur-
sue academic excellence within acceptable levels of human cost. (Georgetown University) 
6. Philosophy

7. Self-Concept

8. Concern for Public Image
The School's approach is based on the belief that three cornerstones are essential to the development of a quality educational program: 1) the motivated student . . . ; 2) a faculty dedicated to the highest standards in teaching and research ; and 3) a curriculum of sufficient depth, breadth, and flexibility to meet diverse student needs and expectations. (Atlanta University)

Along with emphasis on academic quality goes an active effort to use the University's extraordinary locational advantage to build a strong interface with the business, banking, and professional groups in the city, as well as to develop an equally strong set of ties to leading foreign universities. (New York University)

The overall goal of the University of Miami School of Business Administration is to achieve and maintain a position of nationally acknowledged quality within the top fifteen private university schools of business administration in the United States... . (University of Miami)

More important, the strategy fits well into the demographic trends of the 80's, for it positions us among the 10 best undergraduate business schools in the nation, with only the Wharton School at Pennsylvania as a competitor in the Northeast. (New York University)

\section{Communication Analysis}

Even though the mission statement includes the necessary components, its communication effectiveness may be poor. Recent writings involving "corporate culture" and successful companies have emphasized the significance of effective communications between the organizations many constituents. (Peters \& Waterman, 1982; Kennedy, 1984)

Kennedy reports:

The companies and organizations that do the best job thinking through what they are all about, deciding how and to whom these central messages should be communicated and executing the communication plan in a quality way invariably build a strong sense of esprit within their own organization and among the many constituents they serve. (Kennedy, 1983, p. 26)

Since written communication involves denotative as well as connotative meanings both are suggested as part of the community analysis for mission statement development. (Bradley \& Baird, 1983) 


\section{Denotative Analysis}

This aspect or stage is defined as determining the readability of the mission statement - e.g., is it written in a clear and concise manner? A classic readability index called the Fog Index is an appropriate technique to measure readability (Blundell, 1980). Table 2 illustrates how the Fog Index computed. The mission statement committee would evaluate their drafted Mission Statement to determine its readability index. If the index was considered too high for their average readership they would rewrite the MS draft by reducing sentence length and usage of multiple syllabled words.

\section{Table 2}

\section{Steps in Determining A Mission Statement's Readability Level}

1. Compute The Number of Words

2. Compute The Number of Sentences

3. Compute The Average Number Of Words Per Sentence (Item 1 divided by item 2)

4. Compute The Number of Hard Words (Treat as hard words all words of three or more syllables, abbreviations and symbols. Do not count capitalized words, unless symbolized or abbreviated.)

5. Compute The Number of Hard Words Per 100 Words (Item 4 divided by Item 1 times 100)

6. Compute The Sum Of The Word Average And The Hard Word Percent (Item 3 plus Item 5)

7. Compute The Fog Index Which Indicates The Readability Level (Item 6 multiplied by 0.4)

Source: Adapted from How to Take The Fog Out of Writing by Robert Gunning and Dougles Mueller, Chicago, Illinois: The Dartnel Corporation, revised edition, 1981.

\section{Connotative Analysis}

In their book entitled Communication for Business and Professions, Bradley and Baird reveal that the connotative meanings and emotional aspects of a written document are important. Relating this to development of a good mission statement, a Mission Statement should arouse one's feelings and emotions for an organization. That is, an effective mission statement results in feelings that a particular organization is successful, knows where it is going, and is worthy of the reader's time, support, and investment. A good mission statement does more than simply include the needed components; it is also inspiring and motivating. Quinn (1980) states that such a statement should create elan or create an identity larger than the limits placed 
upon the firm by the individuals themselves. Zaleznik (1970) has found that effective organizational "missions" help satisfy people's needs to produce something worthwhile, to gain recognition, help others, to beat opponents or earn respect. Furthermore, according to Quinn, the firms must distinguish themselves from all others in the competitive environment. So far, at least, the mission statement must transcend the criteria usually attributed to objectives such as measurable, achievable, etc. in that it should lift the firm above its present state. Keller (1983) reminds managers that what is important is the quality, daring and sagacity of the strategy.

This connotative step for the Mission Statement committee involves asking managers to evaluate the mission statement using words that describe the feelings management wanted to be communicated. The feelings/impressions that should be present are only briefly discussed in the literature. Glueck (1980) mentions such things as coherence, agreed upon, top down, etc., while Quinn (1980) includes elan in the description.

Other concepts/words may be more representative for a particular organization and may be developed by the management team; however, the following terms are offered as suggested words to use when measuring the "felling" that others perceive to be inherent in the mission statement, the connotative meanings.

Optimism - the impression that while the goals are large they can be achieved Certainty - impressions of resoluteness, completeness, commitment Aggressiveness - impressions of assertiveness or competitiveness

Inspiration - impression of vision, far reaching nature

Concreteness - references to recognition of environmental influences, explicitness, and clarity

Activity - impressions of implementation of ideas, motion forward

To measure whether these feelings are present, managers should be asked to indicate their level of agreement or disagreement with several statements or questions related to these terms as reflected in their mission statement. Table 3 suggests a format for measurement. 


\section{Table 3}

\section{Suggested method of Measuring Connotative Feelings}

\section{Generated by Mission Statement}

Scale Used

$$
\begin{aligned}
& 1=\text { Strongly Disagree } \\
& 2=\text { Disagree } \\
& 3=\text { Neither Agree nor Disagree } \\
& 4=\text { Agree } \\
& 5=\text { Strongly Agree }
\end{aligned}
$$

Concept

Scale

OPTIMISM (Not shown on rating sheet)

1. This mission statement gives me the feeling that the

$\begin{array}{lllll}1 & 2 & 3 & 4 & 5\end{array}$ university is on the verge of achieving great things.

2. I am hopeful for the future of our organization.

$\begin{array}{lllll}1 & 2 & 3 & 4 & 5\end{array}$

3. The mission of the organization is uninspiring.

4. The goals included in the plans for the future are $\begin{array}{lllll}1 & 2 & 3 & 4 & 5\end{array}$ too optimistic.

AGGRESSIVENESS/ASSERTIVENESS (Not shown on rating sheet)

1. We will find it difficult to be competitive in our area in the future.

2. The future of our university will be insured by

$\begin{array}{lllll}1 & 2 & 3 & 4 & 5\end{array}$ following the ideas presented in our mission statement.

3. The goals we have talked about will help us achieve $\quad \begin{array}{lllll}1 & 2 & 3 & 4 & 5\end{array}$ little more than we presently are doing.

4. The direction we will be taking in the future is $\quad 1 \quad 2 \quad 3 \quad 4 \quad 5$ much clearer to me.

INSPIRATION (Not shown on rating sheet)

1. I cannot agree with much of what we have decided to do.

2. In my opinion, we will exceed our expectations of success by following the plans included in our mission statement.

3. It is better to be on the safe side than to try some of these ideas.

4. The foresight exhibited in this planning process will help us be prepared for the future better than other colleges I am aware of.

\section{Applicability Analysis}

The fourth step of the process is to measure the extent to which the statement can be applied in a given situation. Use of mini-cases to give the committee an opportunity to apply the direction of the mission statement is suggested to aid 
in the measurement of practicality. Several mini-case situations should be prepared which would require managers to make a decision or recommendation concerning a situation with implications for the various component parts of the statement. The responses or decisions would indicate how well these managers understood the direction provided through the statement as well as their ability to apply the mission statement to the situation. (Cochran \& Gibson, 1979) Table 4 gives one example of such a situation for Wallace Women's College.

\section{Table 4}

\section{Wallace Women's College*}

Wallace's Women's College is a small, exclusive women's college located in North Carolina. Its major purpose is to foster an understanding and appreciation of the intellectual and cultural heritage of man, cultivate the student's love of the beautiful and the good, and prepare graduates to live in society with happiness for themselves and helpfulness to others. This will be accomplished with classes to improve communication, such as math, languages, and music, classes to improve understanding of the human condition, such as literature, history, and philosophy, and classes on which to build professional and civic careers, such as nursing and education. The college will strive to provide quality education with a highly qualified and stable faculty and a high student/teacher ratio. The college will strive to be sensitive to the educational demands of the area, provide an atmosphere conducive to women's liberal education, and provide cultural activities for students and surrounding residents through student activity, concerts, and recitals.

"Rudolph E. Koletic and Lawrence R. Jauch, "Wallace Women's College," in Business Policy and Strategies Management, 4th Ed., by W.F. Glueck, L.

\section{Table 5}

\section{Mini-Case Situation For Wallace Women's College}

Wallace Women's College has recently received an offer of a significant donation from the estate of a retired area businessman who had built a national reputation in his hardware wholesale distributorship. The donation is contingent upon the establishment of a School of Business at the College. The college has been experiencing a decline in enrollment for some time, dropping from a total enrollment of over 900 to 600 over the last nine years. As a result, Wallace Women's College had been operating at a deficit and had been using it's endowment funds and borrowed funds for operating expenses. The proposed education program and endowment could keep the college's finances from deteriorating further and help support the Schools of Music and Nursing. What should be the decision of Wallace Women's College?

Write your recommendation here and justify based on your understanding of your schools Mission Statement.

From this example the college should not accept the donation under the given restraints since it violates the organization's mission statement. The college would need to either convince the donor to change the constraints to be in line with the 
Mission Statement or change the Mission Statement. The point in this example is to see if the organization's Mission Statement can be applied to a typical situation regarding the strategic plan.

\section{Summary}

The mission statement may be the most visible and public part of a firm's strategic plan. As such, steps should be taken to insure that the statement includes all those correspondents critical to the continued success of the organization. In addition, the statement should be critically evaluated to insure that it communicates both an understanding and the desired feeling that will guide or motivate managers to action. Finally, it should be practical.

This article proposes a four step process or model for strategic mission statements. This process may be utilized by "mission statement committees" in all types of organizations; it can be accomplished "in house" with only a minimum amount of time and resources. A process of self-evaluation of the mission statement should help managers view their planning concepts more accurately and help the organization to relate the desired planning direction in a positive and forceful way.

Carefully prepared missions have been the source of success for many companies. Poorly formulated missions have brought disaster to some companies. Revised missions have turned some companies around. A well developed mission statement can be a unifying and motivating light for all the stakeholders of an organization.

An increasing number of organizations today are implementing strategic management concepts. As part of this process, more and more firms are striving to develop a clear and meaningful company mission statement. The framework presented in this article for developing and evaluating mission statements could enhance the strategic management process in organizations. This framework could also provide some direction for much needed empirical research on mission statements.

\section{References}

Bennis, W. G. (1977). Where have all the leaders gone? Technology Review, 79(March/April), 37-46.

Blundell, W. E. (1980). Confused, overstuffed corporate writing often costs versus much time-and money. The Wall Street Journal, (Thursday, August 28).

Bradley, P. H., \& Baird, Jr., J. E. (1983). Communication for business and the professors (2nd ed.). Dubuque, IA: Wm. C. Brown, Co. 
Budd, R. W., Thorp, R. K., \& Donohew, L. (1967). Content analysis of communications. New York: MacMillan Co.

Cochran, D. S., \& Gibson, C. K. (1979). Putting a square peg into a round hole: Communication models and their application. Journal of Business Communication, 17(Fall), 27-36.

Cohen, K. J., \& Cyert, R. M. (1973). "Strategy: Formulation, implementation, and monitoring." The Journal of Business, 46(July), 349-367.

David, F. R. (1984). Towards an integration of strategic management models. Southern Management Association, Proceedings, 195-197.

Drucker, P. F. (1974). Management: Tasks, responsibilities, practices. New York: Harper and Row.

Ferguson, C. R., \& Dickinson, R. (1982). Critical Success Factors for Directors in the Eighties. Business Horizons, (May/June), 14-18.

Gardner, J. W. (1961). Excellence, can we be equal and excellent too. New York: Perennial Library, Harper and Row.

Gardner, J. W. (1964). Self renewal, the individual and the innovative society. New York: Harper and Colophon Books, Harper and Row.

Glueck, W. F. (1980). Business policy and strategic management (3rd ed.). New York: McGraw-Hill Book Co.

Goldhaber, G. M. (1983). Organizational communication (3rd ed.). Dubuque, IA: Wm. C. Brown Co., 411.

Gunning, R. (1952). Techniques of clear writing. New York: McGraw-Hill Publishing.

Hanakawa, S. I. (1976). How words change our lives. In N. Sigband (Ed.), Communication for management and business (2nd ed., pp. 489-496). Flenview, IL: Scott Foresman and Co.

Hollowood, J. R. (1981). College and university strategic planning: A methodological approach. Planning for Higher Education, 9(Summer), 8-18.

Jakobson, R. (1960). Closing statement: Linguistics and poetics. In T. Sebok (Ed.), Style in language. Cambridge, MA: The M.I.T. Press.

Katz, R. L. (1970). Management of the total enterprise. Englewood Cliffs, NJ: Prentice-Hall, 19.

Katz, R. L. (1955). Skills of an effective administrator. Harvard Business Review, 33(January/February).

Kennedy, A. (1984). Back-fence conversations: New tools for quality conversations. Communication World, (November), 2630. 
Koprowski, Eugene J. (1981). Exploring the meaning of good management. Academy of Management Review, 6, 459-467.

Kotler, P. (1982). Marketing for nonprofit organizations (2nd ed.). Englewood Cliffs, NJ: Prentice-Hall, Inc.

Lazer, W., \& Cullev, J. D. (1983). Marketing management, foundations and practices. Boston: Houghton Mifflin Co.

McPherson, M. S. (1983). Value conflicts in American higher education, a survey. Journal of Higher Education, 54(May/June), 243-278.

Myers, J. H., \& Warner, G. W. (1968). Semantic properties of selected evaluation adjectives. Journal of Marketing Research, V(November), 408-412.

Ohmae, K. (1982). The secret of strategic vision. Management Review, (April), 9-13.

Pearce II, J. A. II. (1982). The company mission as a strategic tool. Sloan Management Review, (Spring), 15-24.

Pearce II, J. A., \& Robinson, Jr., R. B. (1982). Strategic management, strategy formulation and implementation. Homewood, IL: Richard D. Irwin, Inc.

Peters, T. J., \& Waterman, R. H. (1982). In search of excellence: Lessons from America's best-run companies. New York: Harper \& Row.

Quinn, J. B. (1980). Strategies for change: Logical incrementalism. Homewood, IL: Richard D. Irwin, Inc.

Staples, W. A. \& Black, K. V. (1984). Defining our business mission: A strategic perspective. Journal of Business Strategies, 1, 33-39.

Vancil, R. F. (1977). Strategy formulation in complex organizations. In P. Lorange \& R. F. Vancil (Eds.), Strategic planning systems. Englewood Cliffs, NJ: Prentice-Hall, 4-22.

Zaleznik, A. (1970). Power and politics in organizational life. Harvard Business Review, (May/June), 47-60. 
